\title{
ANTI-PLATELET FRACTION ISOLATED FROM GALEGA OFFICINALIS
}

\author{
A. Atanasov \\ Department of Physics and Biophysics, Faculty of Medicine, \\ Thracian University - Stara Zagora, Bulgaria
}

\begin{abstract}
Summary. A fraction from crude extract of Galega officinalis has been purified by column chromatography on Sephadex G-25, Sepharose 4B, DEAE-Cellulose and Sephadex G-100. The final purification factor of the fraction is 120 . The peak in elution profile after Sephadex G-150 shows a molecular weight of 100-140 kDa. The isolated fraction appears to have $74 \%$ polysaccharides and $23 \%$ of proteins. No loss of activity of the final fraction is observed after storage for several months at $4{ }^{\circ} \mathrm{C}$ and in lyophilized condition. The fraction compounds inhibit platelet aggregation induced by ADP, collagen and thrombin.
\end{abstract}

Key words: Galega officinalis, antiplatelet fraction

\section{INTRODUCTION}

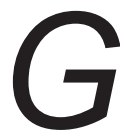
alega officinalis is a plant wide distributed in Yeast Europe. The plant is used in the traditional medicine in the treatment of diabetes mellitus [1]. About 20 biologically - active substances are isolated from Galega officinalis: alkaloids, flavonoids, glucosides, saponin and others. Phytochemical analyses gave positive results for lipids, protein and cellulose [2]. The biologically active alkaloid galegine (exhibiting a hypoglycaemic effect in vivo) was isolated from Galega officinalis [3]. The experimental results of Atanasov shown that the crude aqueous extracts [4,5], and the fractions from gel-chromatography on Sephadex G-25, Sepharose 4b and ion-exchange chromatography on DEAECellulose suppress platelet aggregation in vitro and in vivo induced by ADP, epinephrine, thrombin and collagen [6, 7]. In this paper we report the purification and characterization of all active fractions purified by 4 steps from crude extract of Galega officicnalis. 


\section{MATERIAL AND METHODS}

Plant material and extract preparation. The aerial parts of Galega officinalis at flowering stage were collected between May and August 2015 in different parts of Thrace, region of Bulgaria. Plant was verified by Department of Botany, Faculty of Pharmacy (University of Sofia, Bulgaria).Crude aqueous extracts were obtained by maceration of $200 \mathrm{~g}$ dry matter in $2000 \mathrm{ml}$ distilled water (pH 8 adjusted with sodium hydrogen carbonate) for $20-24$ hours at $18-20^{\circ} \mathrm{C}$. Fresh extracts were filtered and concentrated at temperature below $35^{\circ} \mathrm{C}$ to about $165-170 \mathrm{mg} / \mathrm{ml}$ dry matter.

Isolation procedures. Concentrated crude extract $(10 \mathrm{ml}$ at $75 \mathrm{mg} / \mathrm{ml}$ dry matter) was applied onto a column with Sephadex G-25 $(700 \times 65 \mathrm{~mm})$ equilibrated with $\mathrm{NH}_{3}-\mathrm{H}_{2} \mathrm{O}$ solution, $\mathrm{pH}$ 7.3. The active compound was eluted with the starting buffer at $16^{\circ} \mathrm{C}$ and flow-rate $720 \mathrm{ml} / \mathrm{h}$. The active fraction (400 to $550 \mathrm{ml}$ ) was concentrated and lyophilized. Lyophilized column fraction $(200 \mathrm{mg}$ ) obtained from Sephadex G-25 column was applied to a column with Sepharose-4B $(550 \times 24 \mathrm{~mm})$ equilibrated with $0,01 \mathrm{M}$ Tris- $\mathrm{HCl}, \mathrm{pH}$ 7.3. The active compound was eluted with the same buffer at 16 ${ }^{\circ} \mathrm{C}$ and flow-rate $10 \mathrm{ml} / \mathrm{h}$. The active fraction (120 to $150 \mathrm{ml}$ ) was collected, desalted on Sephadex G-25, concentrated and lyophilized. The lyophilized material (100 mg) from Sepharose 4B was applied onto a column with DEAE-cellulose equilibrated with $0.02 \mathrm{M}$ potassium phosphate, $\mathrm{pH} 7,3$. The active fraction was eluted with the same buffer, desalted on Sephadex G-25, concentrated and lyophilized. The lyophilized material $(24 \mathrm{mg})$ from DEAE-cellulose column was applied onto a column with Sephadex G-100 (52 x $16 \mathrm{~mm})$, equilibrated with 0,01 M Tris-HCl, pH 7.3. The active compound was eluted with the same buffer at $16^{\circ} \mathrm{C}$ and flow-rate $16 \mathrm{ml} / \mathrm{h}$. Active fractions from 25 to $55 \mathrm{ml}$ were collected, desalted on Sephadex G-25, concentrated and lyophilized.

Determination of the molecular weight $\left(M_{w}\right)$. The isolated fraction was applied onto a Sephadex G-150 column $(100 \times 1.5 \mathrm{~cm})$ pre-equilibrated with $0.01 \mathrm{M}$ Tris- $\mathrm{HCl}$, $\mathrm{pH}$ 7.3. ß-amylase $\left(M_{w} 200 \mathrm{kDa}\right)$, alcohol dehydrogenase $\left(M_{w} 150 \mathrm{kDa}\right)$, albumin $\left(M_{w}\right.$ $66 \mathrm{kDa})$, ovalbumin (Mw $43 \mathrm{kDa})$, carbonic anhydrase $\left(\mathrm{M}_{\mathrm{w}} 29 \mathrm{kDa}\right)$ and cytochrome $\mathrm{C}\left(\mathrm{M}_{\mathrm{w}} 12.3 \mathrm{kDa}\right)$ were used as protein standards.

Platelet aggregation-inhibition studies. Blood was taken from volunteers who did not receive medication for 15 days prior to blood collection. Blood was collected in disposable syringes and diluted at a ratio of 1 part 3,8\% trisodium citrate and 9 parts venous blood. Platelet-rich plasma (PRP) was prepared by centrifugation (180 $\mathrm{x} \mathrm{g}$ for $10 \mathrm{~min}$ ) and diluted to $300 \times 10^{6}$ platelets per $\mathrm{ml}$ with autologous platelet-poor plasma ( $1800 \times \mathrm{g}$ for $15 \mathrm{~min}$ ). The platelet aggregation was studied by a photometric method according to Born and Zucker [8]. The extinction change that takes place during the aggregation of $400 \mu$ l platelet-rich plasma compared with platelet-poor plasma (whose extinction was taken as zero) after adding aggregating agent at final concentration $25 \mu \mathrm{M}$ ADP, $100 \mu \mathrm{g} / \mathrm{ml}$ collagen or $0.8 \mathrm{U} / \mathrm{ml}$ thrombin at $37^{\circ} \mathrm{C}$ was the

A. Atanasov 
basis of measurement of the aggregating effect. Theophylline, aspirin and heparin were used as a basis for comparison of the effect of the active fraction on the platelet aggregation.

Reagents and drugs. ADP from Reanal (Hungary), human thrombin and bovine collagen from Research Institute of Hematology and Blood Transfusion (Sofia, Bulgaria) were used as aggregating agents. Theophylline, aspirin and heparin from Pharmachim (Bulgaria) were used as a basis for comparison of the effect of the active fraction on the platelet aggregation.

Statistical analysis. The results were expressed as mean S.E.M.

\section{RESULTS}

Isolation of the active fractions. Column gel-filtration on Sephadex G-25 was used as first step for separation from the substances with low molecular mass (with $M_{w}$ lower than $20 \mathrm{kDa}$ ) (Fig. 1a). Gel-filtration on Sepharose 4B was used for elimination of fraction with high molecular mass (with Mw higher than $200 \mathrm{kDa}$ ) and colored substances (Fig. 1b). Column ion-exchange chromatography on DEAE-cellulose was applied for total elimination of the colored substances. The active fraction was eluted with $20 \mathrm{mM}$ potassium phosphate buffer, $\mathrm{pH}$ 7.3. The colored substances were eluted with gradient of $0.1-3.0 \% \mathrm{NaCl}$ in $20 \mathrm{mM}$ potassium phosphate buffer, $\mathrm{pH}$ 7.3. Gel-filtration on Sephadex G-100 was used as final step for obtaining of a separate active fraction (Fig. 1c). This fraction was pooled, dialyzed and concentrated at temperature below $35^{\circ} \mathrm{C}$. The all purification steps are presented in Table 1.

Table 1. Purification steps of antiplatelet fractions from Galega officinalis

\begin{tabular}{|l|c|c|c|c|c|}
\hline $\begin{array}{l}\text { Purification } \\
\text { step }\end{array}$ & $\begin{array}{c}\text { Total matter } \\
(\mathbf{m g})\end{array}$ & $\begin{array}{c}\text { Specific activity } \\
(\mathbf{U} / \mathbf{m g})^{*}\end{array}$ & Total activity (U) & Purification fold & Yield (\%) \\
\hline Crude extract & $1000.10^{3}$ & 0.9 & $900.10^{3}$ & 1 & 100 \\
\hline Sephadex G-25 & $24.10^{3}$ & 32 & $770.10^{3}$ & 36 & 85 \\
\hline Sepharose 4B & $6.10^{3}$ & 83 & $500.10^{3}$ & 92 & 55 \\
\hline DEAE-Cellulose & $2.5 .10^{3}$ & 90 & $225.10^{3}$ & 100 & 25 \\
\hline Sephadex G-100 & $2.10^{3}$ & 108 & $216.10^{3}$ & 120 & 24 \\
\hline
\end{tabular}

*One unit of specific activity for extract or fraction was taken to be equal to IC50 - this is the quantity of extract or fraction after each step of purification that inhibits with $50 \%$ the platelet aggregation of $1 \mathrm{ml}$ platelet-rich plasma initiated by $25 \mu \mathrm{M}$ ADP. For crude extract IC ${ }_{50}$ was $1.1 \mathrm{mg}$; after Sephadex G-25 IC $\mathrm{C}_{50}$ was $0.030 \mathrm{mg}$; after Sepharose $4 \mathrm{~B} I \mathrm{IC}_{50}$ was $0.012 \mathrm{mg}$; after DEAE-cellulose $\mathrm{IC}_{50}$ was $0.011 \mathrm{mg}$; after Sephadex G-100 IC ${ }_{50}$ was $0.0093 \mathrm{mg}$.

All five steps resulted in 120-fold purification. From $1000 \mathrm{~g}$ dry matter was obtained $2 \mathrm{~g}$ leophylized active compound with $216.10^{3}$ units of total activity. The obtained $24 \%$ yield is sufficient, for example $6.10^{3}$ units activity inhibit with $50 \%$ the platelet aggregation in vitro of $6 \mathrm{~L}$ platelet-rich plasma. 
Determination of the molecular weight $\left(M_{w}\right)$. The molecular weight of the main fraction was estimated to be 100-140 kDa by gel- filtration on Sephadex G-150. Fractions with lower $\mathrm{M}_{\mathrm{w}}$ manifesting activity were also identified - Fig. 2.
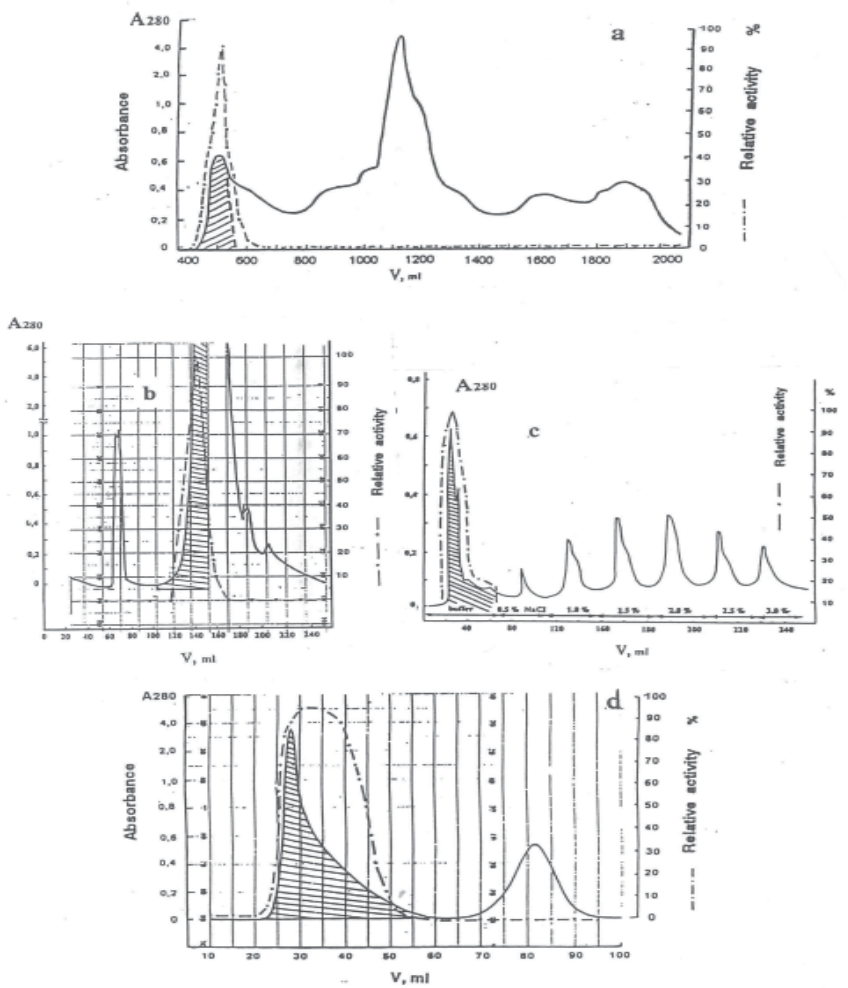

a. Gel-filtration on Sephadex G-25;

b. Gel-filtration on Sepharose 4B;

c. lon-exchange chromatography on DEAE-cellulose; d. Gel-filtration on Sephadex G-100

Fig.1. Purification of an active fraction from $G$. officinalis crude extract

Legend: The solid lines correspond to the eluted fractions. The active fraction is indicated by the shaded area.

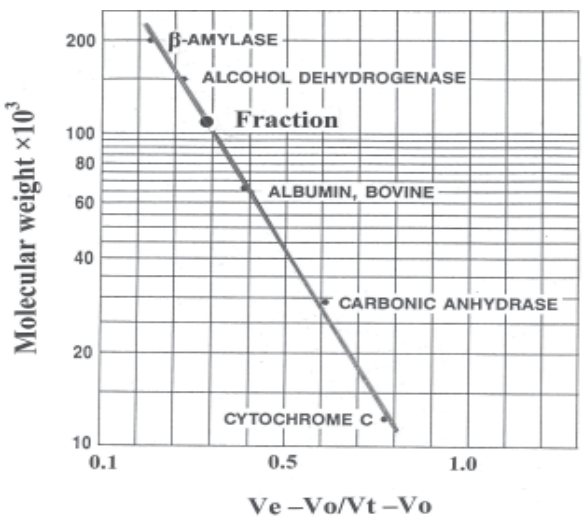

Fig. 2. Determination of molecular weight of the final fraction from $G$. officinalis 
Platelet aggregation-inhibition studies. The 50\% $\left(\mathrm{IC}_{50}\right)$ and $100 \%\left(\mathrm{IC}_{100}\right)$ inhibiting effect of the crude extract and the final fraction (after Sephadex G-100) on platelet aggregation, initiated by ADP, collagen and thrombin in $1 \mathrm{ml}$ PRP was investigated. Data are presented in Table 2.

Table 2. Inhibiting effect on the platelet aggregation of the crude extract, final fraction from G. officinalis and drugs $\left(\mathrm{IC}_{50}\right.$ and $\mathrm{IC}_{100}$ are given as $\mu \mathrm{g}$ substance in $\left.1 \mathrm{ml} \mathrm{PRP}\right)$

\begin{tabular}{|l|l|l|l|}
\hline Aggregating agents & Crude extract $(\boldsymbol{\mu g} / \mathrm{ml})$ & Final fraction $(\boldsymbol{\mu g} / \mathrm{ml})$ & Drugs $(\boldsymbol{\mu g} / \mathrm{ml})$ \\
\hline $25 \mu \mathrm{M}$ ADP & $(\mathrm{IC} 50) 1100.0 \pm 30.6$ & $9.3 \pm 0.45$ & Theophylline $250 \pm 0.10$ \\
\hline $0.1 \mathrm{mg} / \mathrm{ml}$ collagen & $(\mathrm{IC} 100) 1870.0 \pm 74.0$ & $12.8 \pm 0.63$ & Aspirin $1800 \pm 63$ \\
\hline $0.8 \mathrm{U} / \mathrm{ml}$ thrombin & $(\mathrm{IC} 100) 3125.0 \pm 98.0$ & $15.1 \pm 0.58$ & Heparin** $0.7 \pm 0.10 \mathrm{U} / \mathrm{ml}$ \\
\hline
\end{tabular}

*Mean \pm SEM for 8 experiments

$\star * \mathrm{U} / \mathrm{ml}$

In the case of aggregation induced by $25 \mu \mathrm{M}$ ADP the activity of the final fraction was found to be 118 times higher than that of the crude extract and 27 times higher than that of theophylline $\left(\mathrm{IC}_{50}\right.$ data are shown in Table 2$)$. The fraction possess $100 \%$ anti-aggregating activity on the platelet aggregation, initiated by $100 \mu \mathrm{g} /$ $\mathrm{ml}$ PRP collagen and 0,8 U/ml thrombin. In a dose, containing 12-16 $\mu \mathrm{g}$ fraction in $1 \mathrm{ml}$ platelet-rich plasma, the fraction inhibited fully the initiation of the platelet aggregation. For comparison $1.8 \mathrm{mg} / \mathrm{ml}$ aspirin and $0.7 \mathrm{U} / \mathrm{ml}$ heparin inhibited fully the platelet aggregation initiated by $100 \mu \mathrm{g} / \mathrm{ml}$ collagen and $0,8 \mathrm{U} / \mathrm{ml}$ thrombin respectively ( $\mathrm{IC}_{100}$ data are presented in Table 2).

\section{DISCUSSION}

he observed activity of the fraction was higher than those of theophylline, aspirin, heparin and other clinically used drugs and substances. For comparison, $\mathrm{IC}_{50}$ of tea catechins (tannins), an active component of the green tea was $200 \mu \mathrm{g} / \mathrm{ml}$ PRP for collagen-induced platelet aggregation [9]. It was found that the anti-platelet snake venom peptide gabonin $\left(\mathrm{M}_{\mathrm{w}} 21100 \mathrm{Da}\right)$ has $\mathrm{IC}_{50}$ between 8.5 and $33.6 \mu \mathrm{g} / \mathrm{ml}$ PRP for human platelet aggregation, stimulated by ADP, thrombin and collagen [10]. The activity of the fraction from Galega officinalis was 9.3 to $15.1 \mu \mathrm{g} / \mathrm{ml}$ for the same aggregating agent, a value that is near to the activity of the snake venom peptide. The disaggregating effect of the fraction on previously - aggregated PRP shown that the fraction's active compounds disrupted the fibrinogen bridges between the aggregating platelets, responsible for the irreversible aggregation [11]. It is well established that the platelet and the thrombus inhibition activities is possible because of some amino acids sequence as RGD, KRDS, RGDW and others [12]. The peptides with same sequences appear as antagonists of fibrinogen receptors on platelet surface $[13,14]$. 


\section{REFERENCES}

1. Egamberdieva D., Berg G., Lingstrцm K., Rдsдen L.A. Alleviation of salt stress of symbiotic Galega officnalis L. (goat's rue) by co-inoculation of Rhizobium with root-colonizing Pseudomonas. Plant Soil. 2013, 369: 453-465.

2. Atanasov A.T., Radev S., Some physico-chemical characteristics, amino acids and polysaccharides content of a fraction with anti-platelet activity isolated from Galega officnalis L. 7th Bulgarian Peptide Symposium, 2016, 10-12 June, Blagoevgrad, Bulgaria.

3. Hoppe H.A., Drogenkunde., 8 edn.,Walter de Gruyter, Berlin, 1975, 1, 1311.

4. Atanasov A.T., Effect of the water extract of Galega officnalis L. on human platelet aggregation in vitro. Phytotherapy Research, 1994, 8, 314-316.

5. Atanasov A.T., An effect of Galega officnalis $L$ extract on platelet aggregation in rat. Journal of Herbs, Spices \& Medicinal Plants, 1996, 3, 71-76.

6. Atanasov A.T., Tchorbanov B., On the chemical composition of a fraction from Galega officnalis $L$. with anti-aggregating activity on platelet. Comptes rendus de l'Acade'mie bulgare des Sciences, 2003, 56, 31.

7. Atanassov A.T., Tchorbanov B., Synthetic and natural peptides as antithrombotic agents -a view on the current development. Biotechnology and Biotechnology Equipment, 2009, 23, 1109.

8. Zucker M.B., Platelet aggregation measured by the photometric method. Methods in Enzymology, 1989, 169, 118-133.

9. Sagesaka M.Y., Miwa M., Okada S., Platelet aggregation inhibitors in hot water extract of green tea. Chem. Pharm. Bull. Tokyo, 1990, 38, 790-793.

10. Huang T.F., Peng I.S., Teng C.M., Quyang C.H., A novel a-type fibrinogenase from Agkistrodon rhodostoma snake venom. Arch. Biochem. Biophys., 1992, 298, 13-20.

11. Atanasov A.T., Mechanism of action of a fraction isolated from Galega officnalis L. studied by flow cytometry assays with monoclonal antibodies. Anniversary Conference of the Roumen Tsanev Institute of Molecular Biology, 5-6 October, 2015.

12. Danalev D., Yotova L., Vezenkov L. Investigation of the inhibiting effect of Phe-lle-Arg-Pro-Lys-Arg on the serine protease.Bulg. Chem. Commun., 2006, 38, 3-6.

13. Rutherfurd K.J., Gill H.S. Peptides affecting coagulation. British Journal of Nitrition, 2000, 84, S99S102.

14. Moriarty R., McManus C.A., Lambert M., Devocelle M., Brennan M., Kerrigan W., Cox D., A novel role for the fibrinogen Asn-Gly-Arg (NGR) motif in platelet function. Thrombosis and Haemostatsis, 2014, 113, 1-39.

\section{Corresponding author:}

Assoc. Prof. Atanas Atanasov, PhD

Department of Physics and Biophysics

Medical Faculty, Trakian University

Armeiska Str. 11

$\mathrm{Bg}-6000$ Stara Zagora

GSM 0899192976

e-mail: atanastod@abv.bg 